Article

\title{
Cognitive Creationism Compared to Young-Earth Creationism
}

\author{
Shuichi Tezuka (pseudonym) \\ Author email: S.Tezuka@protonmail.com
}

Submitted: 19 May 2020, accepted: 14 September 2020, published: 25 April 2021

\begin{abstract}
Cognitive creationism" is a term for ideologically based rejection of concepts from differential psychology or behavioral genetics. Various authors have compared this practice to young-Earth creationism, but the parallels between the two have not previously been subjected to an in-depth comparison, which is conducted for the first time in this paper. Both views are based on a similar set of psychological needs, and both have developed epistemologically similar worldviews, which draw certain conclusions ahead of time and then interpret all evidence in light of these assumptions. This reversal of the scientific method leads both young-Earth creationists and cognitive creationists to reject large swaths of otherwise well-established research due to its potential to support conclusions they have chosen a priori to reject. Both views also tend to rely on nonparsimonious ad hoc explanations, which are usually not able to reliably predict any future results. The risks posed by cognitive creationism will be discussed, along with potential implications for science education.
\end{abstract}

Keywords: religion; creationism; intelligence; behavioral genetics; horseshoe theory; philosophy of science

How to cite: Tezuka, S. (pseudonym) Cognitive Creationism Compared to Young-Earth Creationism. Journal of Controversial Ideas 2021, 1(1), 3; doi:10.35995/jci01010003.

(C) 2021 Copyright by the author. This article is an open access article distributed under the terms and conditions of the Creative Commons Attribution (CC BY 4.0) license.

(c) (i)

\section{Introduction}

Science denialism exists on both the political right and the political left. A pair of studies by Ditto et al. and Washburn and Skitka have found that conservatives and liberals are about equally likely to deny scientific conclusions that conflict with their political views. ${ }^{1,2}$ However, these studies did not examine whether science

1 Ditto, P. H., Liu, B. S., Clark, C. J., Wojcik, S. P., Chen, E. E., Grady, R. H., Celniker, J. B., \& Zinger, J. F. (2018). At least bias is bipartisan: A meta-analytic comparison of partisan bias in liberals and conservatives. Perspectives on Psychological Science, 14 (2), 273-91. doi:10.1177/1745691617746796.

2 Washburn, A. N., \& Skitka, L. J. (2018). Science denial across the political divide: Liberals and conservatives are similarly motivated to deny attitude-inconsistent science. Social Psychological and Personality Science, 9 (8), 972-80. doi:10.1177/1948550617731500. 
denialism is psychologically and epistemologically similar at opposite political poles. This paper will compare the psychological bases, approaches and tactics of two types of science denialism-young-Earth creationism and the set of beliefs known as "cognitive creationism"-which are, respectively, most widespread on the political right and on the left.

\subsection{Defining Cognitive Creationism and Young-Earth Creationism}

In this paper, I will be using the term "cognitive creationism" for two related concepts: the rejection of widely accepted concepts from behavioral genetics or differential psychology, and the rejection of certain hypotheses related to this field (widely accepted or not) a priori on moral rather than empirical grounds. The term "cognitive creationism" was coined by Michael Shermer for a related but somewhat narrower set of beliefs: that evolutionary forces have shaped humanity only below the neck, while our minds are blank slates controlled by cultural and social influences. ${ }^{3}$ Similar terms for related concepts are liberal creationism ${ }^{4}$ and new creationism, ${ }^{5}$ both of which refer to the morally based rejection of theories about the influence of genes on human abilities and behavior.

Shermer's term is preferable to "liberal creationism" and "new creationism" as it is more accurately descriptive than the other two. First, not all advocates of this viewpoint are actual liberals-for example, Jerry Bergman (discussed in Section 3.1) has argued for some cognitive creationist ideas but is a fundamentalist Christian. It is also inaccurate to refer to this set of viewpoints as "new", as the concept of the mind as a blank slate dates back to pre-Darwinian philosophers such as John Locke and Jean-Jacques Rousseau. ${ }^{6}$

It is widely accepted in psychology that variation in IQ scores among individuals has a significant genetic component. ${ }^{7,8,9}$ The standard textbook Psychology (8th ed.) provides the following summary:

Every procedure for assessing heritability involves assumptions that may not be entirely true, so any heritability coefficient should be taken as only a rough estimate. But the studies suggest, overall, that genetic differences account for roughly 30 to 50 percent of the IQ variance among children and for considerably more than 50 percent of the IQ variance among adults in the populations that were studied (McGue et al., 1993; Nisbett et al., 2012). ${ }^{10}$

Although the genetic contribution to individual variation in IQ scores is well-established, there is no consensus as to why the average scores of some ethnic groups are higher or lower than those of others, and whether or not these group differences include a genetic

3 Shermer, M. (2017). For the love of science. Scientific American, 318 (1), 77. doi:10.1038/scientificamerican0118-77.

4 Young, T. (2018). Opinion: 2017 Constance Holden Memorial Address: Liberal creationism. Intelligence, 66, 2-7. doi:10.1016/j.intell.2017.09.005.

5 Anomaly, J. (2016). The New Creationists. The James G. Martin Center for Academic Renewal. Retrieved 24 April 2020, from https://www.jamesgmartin.center/2016/01/the-new-creationists/.

6 Pinker, S. (2002). The Blank Slate: The Modern Denial of Human Nature (pp. 5-8). New York: Penguin.

7 Knopik, V. S., Neiderhiser, J. M., DeFries, J. C., \& Plomin, R. (2017). Behavioral Genetics (7th ed., pp. 170-71). New York: Worth Publishers.

8 Plomin, R., \& von Stumm, S. (2018). The new genetics of intelligence. Nature Reviews Genetics, 19 (3), 148-59. doi:10.1038/nrg.2017.104.

9 Ashton, M. C. (2018). Individual Differences and Personality (3rd ed., pp. 249-52). London: Academic Press.

10 Gray, P., \& Bjorklund, D. (2018). Psychology (8th ed., p. 389). New York: Worth Publishers. 
component. ${ }^{11,12,13}$ Therefore, "cognitive creationism" or similar terms should not be applied to scholars such as James Flynn and Jelte Wicherts, who have argued that group differences in IQ scores are environmentally caused, ${ }^{14,15}$ as that position is compatible with the current state of evidence from psychology and genetics. In this paper the term "cognitive creationism" is used exclusively for the denial of established psychological science, such as denying that genes have an effect on individual variation in cognitive ability, as well as for the rejection of hypotheses on moral rather than empirical grounds.

Young-Earth creationism (YEC) is the belief that God created the world in more or less its present form sometime in the past 10,000 years, as is suggested by a literal reading of the early chapters of the book of Genesis. The year most commonly given by young-Earth creationists for the creation of the universe is 4004 B.C., based on a calculation made from the Bible's genealogies by the 17th-century bishop James Ussher. ${ }^{16}$ Other tenets of this view include that Adam and Eve were a pair of literal people, from whom all of humanity is descended; that Noah's flood was a real event that covered the entire Earth; and that to the extent that speciation is possible, it cannot occur beyond the limits of certain biological categories known as created kinds or "baramins". ${ }^{17}$ For example, humans and other apes are considered to be separate baramins, so young-Earth creationists regard it as possible for two ape species to share a common ancestor, but not for humans to share a common ancestor with apes.

The terms "creationism" and "intelligent design" are sometimes used interchangeably, and there is significant overlap in the arguments employed to defend both views, but the two are not identical. Traditional creationism posits that the creation account given in the book of Genesis is historically accurate, and that all parts of the Bible are the plainly written Word of God. ${ }^{18,19}$ On the other hand, the goal of the Intelligent Design (ID) movement is to argue that life had some sort of designer, usually without specifying the designer's exact nature. While support for ID comes primarily from the religious right, ID's proponents hold a wide variety of religious beliefs, including a few non-Christian ones. ${ }^{20}$ Unlike the YEC movement, the ID movement generally does not make arguments for the literal existence of Adam and Eve, the occurrence of a global flood, or a young Earth.

It is YEC, rather than ID, that has the most in common with cognitive creationism. Other researchers who have drawn analogies between the two viewpoints have focused on two similarities: many adherents of cognitive creationism do not accept that complex

11 Hunt, E. (2011). Human Intelligence (p. 425). New York: Cambridge University Press.

12 Ritchie, S. (2015). Intelligence: All That Matters (pp. 106-7). London: John Murray Learning.

13 Haier, R. J. (2017). The Neuroscience of Intelligence (p. 34). New York: Cambridge University Press.

14 Flynn, J. R. (2010). The spectacles through which I see the race and IQ debate. Intelligence, 38 (4), 363-66. doi:10.1016/j.intell.2010.05.001.

15 Wicherts, J. M., Borsboom, D., \& Dolan, C. V. (2010). Why national IQs do not support evolutionary theories of intelligence. Personality and Individual Differences, 48 (2), 91-96. doi:10.1016/j.paid.2009.05.028.

16 Barr, J. (1985). Why the world was created in 4004 BC: Archbishop Ussher and Biblical chronology. Bulletin of the John Rylands University Library of Manchester, 67 (2), 575-608. doi:10.7227/BJRL.67.2.2.

17 Answers in Genesis. (2015). Statement of Faith. Retrieved 24 April 2020, from https://answersingenesis. org/about/faith/.

18 Smith, C. (2013). Is there a universal way Christians should interpret the Bible? Creation Ministries International. Retrieved 24 April 2020, from http://creation.com/is-there-a-universal-way-christiansshould-interpret-the-bible.

19 "Plainly written" means that the context of the text alone should determine how it is read, so that it is assumed to be literal unless the text itself presents a reason to think otherwise.

20 Ross, M. R. (2005). Who believes what? Clearing up confusion over Intelligent Design and young-Earth creationism. Journal of Geoscience Education, 53 (3), 319-23. doi:10.5408/1089-9995-53.3.319. 
human behavior was subject to evolutionary forces, and most of them reject scientific conclusions because those conclusions conflict with their political convictions, just as young-Earth creationists reject the theory of evolution because it conflicts with their religious beliefs. However, the similarities between these two worldviews run far deeper, as will be shown in the next two sections.

\section{The Basics of Cognitive Creationism}

\subsection{Background}

Variation in the tendency to be religious is moderately heritable, with the portion of variance attributable to genetic factors rising from $12 \%$ in adolescence to $44 \%$ in adulthood. ${ }^{21}$ In Malaysia, the United States, and several European nations, religiosity is positively correlated with fertility, suggesting that over time these countries have a genetic trend towards higher religiosity. ${ }^{22,23}$ Despite this trend, the religiosity of most Western countries has declined rapidly since the beginning of the 21 st century. Within the ten years from 2009 to 2019, the portion of Americans who did not identify as belonging to any religion rose from $17 \%$ to $26 \%$, with a corresponding decline in all Christian denominations. ${ }^{24}$ These two contrasting lines of data suggest that while religiosity itself has declined, our underlying instincts for religiosity probably have not, as the genetic variants predisposing individuals towards religiosity have become more common among the populations studied.

Religions exist to fulfill several psychological needs: particularly the need to find meaning in life, the need for a sense of control (both control of one's world and self-control), and the need to define a community with a shared set of beliefs. ${ }^{25}$ Jon Shields has suggested that in modern times, many people on the political left seek fulfillment of these and similar needs in the area of politics instead of from traditional religions. ${ }^{26}$ Shields' hypothesis is able to explain the paradoxical relationship between genetic influences on religiosity and religiosity itself: the result of this genetic trend may have been for politics to increasingly take on religious elements, even as traditional religions decline in popularity.

The incorporation of religious elements into leftist politics was examined by James Lindsay and Mike Nanya, who conclude that leftist identity politics represent "a roughly religious structure that services the same human needs that religions do from within a remarkably different paradigm". Religion-like aspects of this structure include the formation of a moral tribe, the adoption of a social mythology to explain the world (in which the structure of society is shaped by conflict between groups defined by race, gender and

21 Koenig, L. B., McGue, M., Krueger, R. F., \& Bouchard, T. J., Jr. (2005). Genetic and environmental influences on religiousness: Findings for retrospective and current religiousness ratings. Journal of Personality, 73 (2), 471-88. doi:10.1111/j.1467-6494.2005.00316.x.

22 Ellis, L., Hoskin, A. W., Dutton, E., \& Nyborg, H. (2017). The future of secularism: A biologically informed theory supplemented with cross-cultural evidence. Evolutionary Psychological Science, 3 (3), $224-42$. doi:10.1007/s40806-017-0090-z.

23 Hubert, S. (2014). The Impact of Religiosity on Fertility: A Comparative Analysis of France, Hungary, Norway, and Germany. Bochum: Springer VS.

24 Pew Research Center. (2019). In U.S., decline of Christianity continues at rapid pace. Retrieved 24 April 2020, from https://www. pewforum.org/2019/10/17/in-u-s-decline-of-christianity-continues-at-rapid-pace/.

25 Hood, R. W., Hill, P. C., \& Spilka. B. (2018). The Psychology of Religion: An Empirical Approach (5th ed., pp. 17-25). New York: The Guilford Press.

26 Shields, J. A. (2006). Spiritual politics on the left. Society, 43 (6), 57-62. doi:10.1007/BF02698487. 
sexual orientation), a focus on an inwards search for recognition of one's unconscious wrongdoing or unacknowledged privilege, and the importance of publicly demonstrating one's commitment to the belief system. The religious aspect of leftism most germane to this paper is what Lindsay and Nanya describe as the adoption of sacred or sacrosanct beliefs:

Sacred beliefs are ones that have been for moral reasons removed from the realm of skepticism and doubt because they're viewed as too important to be subjected to these corrosive influences. Instead, sacred beliefs are effectively set aside from rational inquiry, which results in an expectation for them to be understood mythologically rather than literally, technically, or scientifically. ${ }^{27}$

Neither Christianity nor political leftism is inherently antiscience. Numerous Christian authorities have argued that the theory of evolution is both scientifically correct and compatible with Christian faith-notably, the two most recent popes ${ }^{28,29}$ as well as the roughly 15,500 Christian clergy who signed an open letter to this effect. ${ }^{30}$ Likewise, $^{2}$ in The Blank Slate, Steven Pinker argues that discoveries about the genetic basis of human abilities and behavior need not threaten liberal ideals such as equal rights for all individuals, as these moral values exist independently of any empirical conclusions about psychology or genetics. ${ }^{31}$ However, for some Christians and some leftists, these reassurances are not enough, and certain ideas are regarded as fundamentally incompatible with their worldviews.

\subsection{The Creationist Theory of Knowledge}

The goal of the reassurances given by Pinker, Pope Benedict and Pope Francis is to encourage Christians and leftists to allow the scientific method to proceed unimpeded even in cases in which it produces results that one finds religiously or socially troubling. However, when a person's religious or political convictions are sufficiently strong, or their devotion to the scientific method is sufficiently weak, they may be unwilling to accept results that challenge their religion or their politics. The psychology behind this process was examined by Matteo Colombo, Leandra Bucher and Yoel Inbar, who found that people are less likely to accept scientific conclusions if they found those conclusions to be morally offensive. ${ }^{32}$

Colombo et al.'s study suggests that humans in general are vulnerable to the described effect, but it is a goal of the scientific method to avoid this effect as much as possible because whether or not an idea morally offends cannot tell us whether it is true. This principle of science was described by Hans Eysenck: "We may not like the facts,

27 Lindsay, J., \& Nanya, M. (2018). Postmodern religion and the faith of social justice. Areo Magazine. Retrieved 24 April 2020, from https://areomagazine.com/2018/12/18/postmodern-religion-and-the-faithof-social-justice/.

28 Pope Benedict XVI. (2007). Meeting of the Holy Father Benedict XVI with the clergy of the dioceses of Belluno-Feltre and Treviso. Libreria Editrice Vaticana. Retrieved 24 April 2020, from http://w2.vatican.va/ content/benedict-xvi/en/speeches/2007/july/documents/hf_ben-xvi_spe_20070724_clero-cadore.html.

29 Pope Francis. (2014). Pope Francis' address at inauguration of bronze bust of Benedict XVI. Zenit. Retrieved 24 April 2020, from https://zenit.org/articles/pope-francis-address-at-inauguration-of-bronzebust-of-benedict-xvi/.

30 Clergy Letter Project. (2020). An open letter concerning religion and science. Retrieved 24 April 2020, from https://www.theclergyletterproject.org/Christian_Clergy/ChrClergyLtr.htm.

31 Pinker 2002, pp. 145-51.

32 Colombo, M., Bucher, L., \& Inbar, Y. (2016). Explanatory judgment, moral offense and value-free science. Review of Philosophy and Psychology, 7 (4), 743-63. doi:10.1007/s13164-015-0282-z. 
but they are stubborn; facts are the products of nature, and scientists are merely the messengers who seek and pass on the messages nature has for us". ${ }^{33}$ On the other hand, the central idea behind both young-Earth creationism and cognitive creationism, which I refer to as the "creationist theory of knowledge", is that the psychological process described by Colombo et al. should be embraced instead of avoided. Instead of searching for the set of models that is most consistent with the empirical data, the creationist theory of knowledge is that one should begin with an unalterable set of conclusions, and then search for ways to interpret the data to match those conclusions. In this respect it is the exact reverse of the scientific method, which normally operates by drawing inferences from observation, and then testing whether those hypotheses can be falsified by new results. Answers in Genesis, the most prominent creationist organization in the United States, has described the creationist theory of knowledge in their statement of faith:

By definition, no apparent, perceived or claimed evidence in any field, including history and chronology, can be valid if it contradicts the scriptural record. Of primary importance is the fact that evidence is always subject to interpretation by fallible people who do not possess all information. ${ }^{34}$

Among secular liberals, the expectation that empirical hypotheses must match one's predetermined worldview is described by Bo and Ben Winegard as "Paranoid Egalitarian Meliorism" (PEM). According to this model, people who hold racial or gender equality as a fundamental ideal may be instinctively hostile towards theories that they perceive as a threat to those ideals. ${ }^{35}$ As with perceived threats to Christianity, a theory attacked on the basis of PEM does not necessarily represent a threat to ideals of equality; it is enough for it to be perceived as one. The way in which PEM can be applied to a hypothesis was described by behavioral geneticist Eric Turkheimer:

Why don't we accept racial stereotypes as reasonable hypotheses, okay to consider until they have been scientifically proven false? They are offensive precisely because they violate our intuition about the balance between innateness and self-determination of the moral and cultural qualities of human beings [...] it is a matter of ethical principle that individual and cultural accomplishment is not tied to the genes in the same way as the appearance of our hair. ${ }^{36}$

Turkheimer gave a similar explanation in a 2012 obituary for J. Philippe Rushton, a controversial psychologist best known for his research about race and intelligence:

Rushton knew a great deal about human intelligence and he made his case by marshaling rational arguments based on empirical data. His knowledge and his empiricism earned him a legitimate place at the scientific table. He was no crank. Nevertheless, there is no escaping the fact that the case he made was literally racist, and in my view no appeal to empirical data can rescue his hypotheses from their dubious origins and destructive consequences. ${ }^{37}$

33 Eysenck, H. (1998). Intelligence: A New Look (p. 11). New Brunswick, NJ: Transaction Publishers.

34 Answers in Genesis 2015.

35 Winegard, B., \& Winegard, B. (2018). Paranoid egalitarian meliorism: An account of bias in the social sciences. In J. T. Crawford \& L. Jussim (Eds.), The Politics of Social Psychology (pp. 193-209). New York: Routledge.

36 Turkheimer, E. (2007). The theory of innate differences. Cato Unbound. Retrieved 24 April 2020, from https://www.cato-unbound.org/2007/11/21/eric-turkheimer/race-iq.

37 Quoted in: Allemang, J. (2012). Philippe Rushton, professor who pushed limits with race studies, dead at 68. The Globe and Mail. Retrieved 24 April 2020, from https://www.theglobeandmail.com/news/national/ philippe-rushton-professor-who-pushed-limits-with-race-studies-dead-at-68/article4901806/. 
In summary, this argument posits that some hypotheses must be rejected because they offend our moral principles, and that when a hypothesis is rejected for this reason, "no appeal to empirical data can rescue [it]". A case in which this perspective was used to more specific effect occurred during the 2013 controversy over Jason Richwine's writings about IQ and immigration, in which 23 student groups at Harvard University prepared a joint statement denouncing Richwine's doctoral dissertation on that topic. The statement argued:

Even if such claims had merit, the Kennedy School cannot ethically stand by this dissertation whose end result can only be furthering discrimination under the guise of academic discourse. ${ }^{38}$

Nathan Cofnas has reviewed many more cases in which science communicators and academics have argued that theories related to heredity and intelligence can and should be rejected due to their social or moral implications. ${ }^{39}$ At an epistemological level, these arguments have converged on the same viewpoint as the one described in Answers in Genesis' statement of faith: that some hypotheses must be judged based on their compatibility with one's worldview, regardless of what evidence may exist. Sometimes, as in the Richwine example, it is stated explicitly that hypotheses must be rejected for this reason even if they otherwise have merit. Sutton et al. have described the cognitive process behind this attitude: "Our core proposal is that people not only doubt the facts produced by some scientific investigations but that they also perceive them as a threat to collective interests. In turn, this perception motivates cognitive and behavioral responses that serve to neutralize the threat". 40

The literal accuracy of Genesis, and the nonexistence of hereditary differences in average cognitive ability between racial or ethnic groups, are examples of what Lindsay and Nanya refer to as sacred ideas: ideas that, by definition, cannot be challenged by empirical data. The convergence of the far right and the far left on different sets of sacred ideas can be explained by what Jean-Pierre Faye calls "horseshoe theory", in which the positions of the far left and far right are more similar to one another than either is to the political center. ${ }^{41}$

\section{Effects of Similar Worldviews}

\subsection{Arguments from Consequences and History}

The central idea underlying both cognitive creationism and young-Earth creationism is that ideas are accepted or rejected on the basis of their compatibility with one's worldview, but this epistemological basis is not always presented as bluntly as it has been by Answers in Genesis, Turkheimer and the Harvard statement. More often, this argument

38 Quoted in: Jaschik, S. (2013). Should his Ph.D. have been granted? Inside Higher Ed. Retrieved 2 May 2020, from https://www.insidehighered.com/news/2013/05/13/debate-report-immigration-leads-scrutinyharvard-dissertation.

39 Cofnas, N. (2016). Science is not always "self-correcting". Foundations of Science, 21 (3), 477-92. doi:10.1007/s10699-015-9421-3.

40 Sutton, R. M., Petterson, A., Rutjens, B. T., \& Brandt, M. J. (2018). Post-truth, anti-truth, and can't-handle-the-truth: How responses to science are shaped by concerns about its impact. In B. Rutjens \& M. Brandt (Eds.), Belief Systems and the Perception of Reality (pp. 164-78). New York: Routledge.

41 Faye, J. P. (1996). Le Siècle des Idéologies. Paris: Armand Colin. 
is presented in an indirect manner, by arguing that acceptance of heredity or evolution risks undermining society's morals.

Among traditional creationists, this type of argument was most famously made by William Jennings Bryan during his closing statement in the 1925 Scopes Trial, in which he asserted that "Our fifth indictment of the evolutionary hypothesis is that, if taken seriously and made the basis of a philosophy of life, it would eliminate love and carry man back to a struggle of tooth and claw". He went on to describe how acceptance of evolution had increased the popularity of social Darwinism, as well as how the theory of evolution had been used to justify acts such as the fighting of wars and sexual promiscuity. ${ }^{42}$

Since Bryan's time, the decline in the popularity of social Darwinism has forced these sorts of morality-based arguments to rely increasingly on historical examples. A variety of books by young-Earth creationists and intelligent design proponents have taken this approach, including Darwin's Plantation by Ken Ham and Charles Ware ${ }^{43}$ and From Darwin to Hitler by Richard Weikart, ${ }^{44}$ with The Darwin Effect by Jerry Bergman probably being the most thorough example. Bergman describes how the theory of evolution has historically been used as a justification for several totalitarian political movements, as well as its having been used as a justification for classism and sexism. The greatest amount of attention is paid to its influence on the eugenics movement of the early twentieth century, along with the racial discrimination that was also prevalent during that era. Bergman argues that evolution has not merely been misused for these purposes; rather, these sorts of ideologies are argued to be a logical conclusion arising from features of the theory itself. ${ }^{45}$

Among advocates of cognitive creationism, the parallel argument is that acceptance of or research on the heritability of intelligence risks causing racial or class prejudice, especially if this research involves group differences. A typical example of this argument was made in a 2015 paper by Dorothy Roberts:

The belief that intelligence is heritable and can be predicted by tests has legitimated unjust social hierarchies and justified social policies designed to maintain them. There is no evidence that genetic tests for intelligence are necessary or will help to improve education for people from disadvantaged social circumstances. To the contrary, the genetic theory of intelligence will "cut off all possibility of proper nurturance for everyone's intelligence" and provide a justification for the very social structures that prevent the equitable sharing of educational resources. ${ }^{46}$

Like Bergman's argument about the dangers of evolutionary theory, one of Roberts' main lines of argument about the dangers of intelligence research is based on this research's historical association with racism and eugenics. Nearly all morally based attacks on intelligence research incorporate this argument in some way, including The Science and Politics of I.Q. by Leon Kamin, ${ }^{47}$ The Gene Illusion by Jay Joseph, ${ }^{48}$ IQ: A Smart History

42 Young, C. C., \& Largent, M. A. (2007). Evolution and Creationism: A Documentary and Reference Guide (pp. 166-69). Westport, CT: Greenwood Press.

43 Ham, K., \& Ware, A. C. (2007). Darwin's Plantation: Evolution's Racist Roots. Green Forest, AR: Master Books.

44 Weikart, R. (2004). From Darwin to Hitler: Evolutionary Ethics, Eugenics and Racism in Germany. New York: Palgrave Macmillan.

45 Bergman, J. (2014). The Darwin Effect: Its Influence on Nazism, Eugenics, Racism, Communism, Capitalism \& Sexism (p. 23). Green Forest, AR: Master Books.

46 Roberts, D. (2015). Can research on the genetics of intelligence be "socially neutral"? Hastings Center Report, 45 (S1), S50-S53. doi:10.1002/hast.499.

47 Kamin, L. (1974). The Science and Politics of I.Q. (chapters 1-2). Mahwah, NJ: Lawrence Erlbaum Associates.

48 Joseph, J. (2004). The Gene Illusion (chapter 2). New York: Algora Publishing. 
of a Failed Idea by Stephen Murdoch, ${ }^{49}$ and, most famously, The Mismeasure of Man by Stephen Jay Gould. While Bergman's argument is that acceptance of evolution led to these social outcomes, Gould points the arrow of causality in the opposite direction, arguing that the acceptance of intelligence as a measurable and hereditary trait was itself a consequence of society's prejudice. ${ }^{50}$

Unlike most books of their respective genres, both The Darwin Effect and The Mismeasure of Man devote relatively little space to the perceived relation between evolution or IQ and Nazism. In Bergman's case, the reason for this omission is that he has devoted an entire separate book to the argument that Nazism was built upon the foundation of evolutionary theory. ${ }^{51}$ In The Mismeasure of Man, the discussion is confined to a single footnote, quoting an article from 1941 alleging that the Nazis were "upstaging" America in their use of mental testing. ${ }^{52}$ A more typical book in this regard is IQ: A Smart History of a Failed Idea, which devotes a 20-page chapter to the argument that IQ testing was an important part of the Nazis' eugenics policies. ${ }^{53}$ This association is a stretch in all of the books that assert it, as the mental tests used by the Nazis were quite different from the IQ tests used in English-speaking countries, which were banned in Nazi Germany due to being "Jewish". 54,55

In this area, there has been a degree of synergy between Gould's arguments and those made by young-Earth creationists. In The Mismeasure of Man, Gould devotes a chapter to the relationship between brain volume and intelligence, arguing that no such relationship exists, although nearly all of the research that he criticizes is now over 100 years old. ${ }^{56}$ A similar argument is made by Bergman in The Darwin Effect, focusing on research by Francis Galton, one of the same researchers criticized by Gould. ${ }^{57}$ Bergman and Gould both argue that this correlation could not exist because some cognitively impaired individuals have had large brains, while some geniuses have had brains that were smaller than average. The flaw in this argument is that one cannot disprove a correlation with individual counterexamples, and the existence of a correlation between intelligence (as measured using IQ tests) and brain volume is well established. ${ }^{58,59,60}$

This argument about brain volume was initially made by Gould and was later borrowed by young-Earth creationists, but this type of borrowing of arguments has also occurred in the opposite direction. Anthropologist Holly Dunsworth has argued that "genetic and biological determinism have a stranglehold on the popular imagination", and

49 Murdoch, S. (2007). IQ: A Smart History of a Failed Idea. Hoboken, NJ: John Wiley \& Sons.

50 Gould, S. J. (1996). The Mismeasure of Man: revised and expanded (pp. 51-61). New York: W. W. Norton \& Company.

51 Bergman, J. (2012). Hitler and the Nazi Darwinian Worldview. Kitchener, Ontario: Joshua Press.

52 Gould 1996, pp. 224-25.

53 Murdoch 2007, pp. 119-38.

54 Eysenck 1998, p. 7.

55 Rindermann, H. (2018). Cognitive Capitalism: Human Capital and the Wellbeing of Nations (p. 147). Cambridge: Cambridge University Press.

56 Gould 1996, chapter 3.

57 Bergman 2014, pp. 51-52.

58 McDaniel, M. A. (2005). Big-brained people are smarter: A meta-analysis of the relationship between in vivo brain volume and intelligence. Intelligence, 33 (4), 337-46. doi:10.1016/j.intell.2004.11.005.

59 Pietschnig, J., Penke, L., Wicherts, J. M., Zeiler, M., \& Voracek, M. (2015). Meta-analysis of associations between human brain volume and intelligence differences: How strong are they and what do they mean? Neuroscience \& Biobehavioral Reviews, 57, 411-32. doi:10.1016/j.neubiorev.2015.09.017.

60 Gignac, G. E., \& Bates, T. C. (2017). Brain volume and intelligence: The moderating role of intelligence measurement quality. Intelligence, 64, 18-29. doi:10.1016/j.intell.2017.06.004. 
that as a result, "evolution is all wrapped up in white supremacy and a genetically-destined patriarchy". She proposes that in order to combat "biological determinism" and promote egalitarian ideas, classes that teach the theory of evolution must place a greater emphasis on the humanities instead of being entirely about biology, and in particular they must "actively dismantle evolution's racist/etc past and present". ${ }^{61}$ Dunsworth's argument about the present-day risks of evolutionary theory is substantially the same as an argument previously made by young-Earth creationist Tas Walker at Creation Ministries International, in which Walker asserts that evolutionary theory inevitably promotes racist stereotypes, and warns his readers "Don't let them subconsciously turn you into a racist with their subtle evolutionary icons". ${ }^{62}$ Unlike Walker and Bergman, Dunsworth does not dispute the factual correctness of the theory of evolution, but her argument against it being taught as a straightforward conclusion of the scientific method also parallels the past proposals by creationists and intelligent design advocates that biology classes must include "critical analysis of evolution", ${ }^{63}$ or should include disclaimers on biology textbooks describing evolution as a "controversial theory". ${ }^{64}$

The parallel cases of Bergman and Dunsworth are explained by horseshoe theory. While these two authors have begun, respectively, from a right-wing and left-wing point of view, these disparate viewpoints have led them to a set of conclusions that are similar to those held at the opposite political pole. This convergence occurs because when evidence is forced to conform to one's predetermined worldview, some of the same ideas are perceived as equally dangerous whether that worldview comes from the left or the religious right. The idea that brain volume could be statistically related to intelligence, for example, is perceived as dangerous by proponents of cognitive creationism because it is an important part of the argument that ethnic group differences in average IQ scores have a biological basis, ${ }^{65}$ and by young-Earth creationists because the evolution of large brains as an adaptation for higher intelligence was one of the most important transitions in the evolution of humans from apes. ${ }^{66}$ This practice of rejecting any line of evidence that could support a forbidden idea is examined more closely in the next section.

\subsection{Demands for Purity and the Domino Effect}

When ideas are accepted or rejected on the basis of their religious or social implications, there is a unique effect not found in most areas of science. This effect is a demand for a form of purity, according to which it is not enough to merely reject the forbidden idea itself.

61 Dunsworth, H. (2018). It is unethical to teach evolution without confronting racism and sexism. The Evolution Institute. Retrieved 24 April 2020, from https://evolution-institute.org/it-is-unethical-to-teachevolution-without-confronting-racism-and-sexism/.

62 Walker, T. (2008). Evolution is inherently racist. Creation Ministries International. Retrieved 11 May 2020, from https://creation.com/evolution-is-inherently-racist.

63 Matzke, N. (2006). No one here but us Critical Analysis-ists... The Panda's Thumb. Retrieved 24 April 2020, from https://pandasthumb.org/archives/2006/07/no-one-here-but.html.

64 Schlanger, Z. (2015). Here's the evolution-questioning 'sticker' Alabama puts on its biology textbooks. Newsweek. Retrieved 24 April 2020, from https://www.newsweek.com/alabama-biology-textbooksevolution-sticker-373662.

65 Hunt 2011, pp. 433-34.

66 Keesey, T. M. (2016). Three histories of the human body. In J. Kane, E. Willoughby, T. M. Keesey, G. Morton \& J. Comer. God's Word or Human Reason?: An Inside Perspective on Creationism (pp. 189-264). Portland, OR: Inkwater Press. 
One is also expected to reject any other ideas that are perceived as being associated with it, and there are varying opinions on how far this association extends.

A case of this effect can be seen in discussions of the YEC model known as Recolonization Theory. Like most young-Earth creationists, proponents of Recolonization Theory generally believe that the Earth is thousands rather than millions or billions of years old, and that Noah's flood covered the entire Earth. However, while the prevailing creationist explanation for the fossil record is that most of it was deposited by the Flood, Recolonization Theory proposes that fossil succession instead represents the order that plants and animals recolonized the world after the Flood was over. ${ }^{67}$ The advantage of this model over traditional Flood geology models is that the fossil record contains many features that cannot easily be explained as forming during a global flood, such as desiccation mudcracks and dinosaur nests and eggs. Instead of trying to explain how these features formed during the Flood, Recolonization Theory accepts that they were formed in a depositional environment similar to the one that exists in the present. ${ }^{68}$

All proponents of Recolonization Theory regard Genesis as a literal history. However, among many professional young-Earth creationists, the model is still considered unacceptable because it relies too heavily on ideas from mainstream geology. This objection to Recolonization Theory is explained in a critique of the model by the creationists Andy Mclntosh, Steve Taylor and Tom Edmondson, which was later quoted by Answers in Genesis: ${ }^{69}$

Their admission that the biblical exegesis is not the key reason for espousing their Flood model, shows the weakness of their thinking. Their science is driving their interpretation of Scripture, and not the other way round. From this unproven (and in our opinion false) premise, they construct a model that owes more to a desired allegiance to the geological column than to Scripture. ${ }^{70}$

A closely related effect is a variant of what is known as the domino effect, by which one event can cause several others in a chain reaction. Very few people are able to engage in the doublethink of rejecting a hypothesis on social or religious grounds while simultaneously accepting that the hypothesis is empirically well-supported. More often, when a hypothesis is rejected for these reasons, every line of evidence to support it must be rejected as well. As the support for a hypothesis may come from many areas, this practice can result in a cascading rejection of conclusions from many separate fields.

The domino effect explains why the major young-Earth creationist organizations reject the existence of feathered dinosaurs. Answers in Genesis explains, "While there's no particular biblical reason for thinking dinosaurs didn't have feathers, we remain cautious because the idea is most often presented in conjunction with the idea that birds evolved from theropod dinosaurs". ${ }^{71}$ A more inevitable case of the domino effect is found

67 Tyler, D. J. (2006). Recolonization and the Mabbul. In J. K. Reed \& M. J. Oard (Eds.), The Geologic Column: Perspectives within Diluvial Geology (pp. 63-86). Chino Valley, AZ: Creation Research Society Books.

68 Morton, G. R. (1982). Fossil succession. Creation Research Society Quarterly, 19 (2), 103-11.

69 White, M., \& Taylor, P. (2006). The 'recolonisation theory'-The latest compromise. Answers in Genesis. Retrieved 24 April 2020, from https://answersingenesis.org/bible-timeline/genealogy/the-recolonisationtheory-the-latest-compromise/.

70 McIntosh, A., Taylor, S., \& Edmondson, T. (2000). Mclntosh, Taylor and Edmondson reply to Flood models. Journal of Creation, 14 (3), 80-82.

71 Answers in Genesis. (2010). Fossilized melanosomes found. Retrieved 24 April 2020, from https:// answersingenesis.org/dinosaurs/feathers/fossilized-melanosomes-found/. 
in the YEC book Unwrapping the Pharaohs, which rejects the standard historical account of ancient Egypt. ${ }^{72}$ Young-Earth creationists reject this account because mainstream histories of Egypt extend back over 7000 years, whereas the major YEC organizations take the position that the universe itself is only about 6000 years old. ${ }^{73}$

The same approach, beginning with the rejection of an idea and then attacking other ideas loosely associated with it, is taken in a 2016 paper by David Gillborn that attacks Robert Plomin, a behavioral geneticist who has written almost nothing about the causes of group differences. According to Gillborn, Plomin's research about the genetic basis of intelligence is a strategy that Gillborn calls "racial inexplicitness", which indirectly advances racist ideas without mentioning race. Gillborn argues:

It is difficult to overemphasize the significance of the historical linkage between ideas of race and ideas of intellectual superiority/inferiority. Even when a discourse does not explicitly mention race, these ideas remain a vital part of the landscape; what Michael W. Apple terms an "absent presence". ${ }^{74}$

Describing research by Plomin and other intelligence researchers, Gillborn subsequently concludes that "[t]he racist patterning of differential educational opportunity and achievement, that is encoded in their views, lies buried in the small-print, hidden from the view of the general reader". Consequently, he gives the following instruction: "Critical educators must quickly adapt to, and interrupt, this version [of racism] or else we may find that scientific racism has reshaped our education systems without even mentioning race". ${ }^{75}$

The perceived relation of behavioral genetics to race research has caused a case of the domino effect, an example of which can be seen in Robert Sussman's 2014 book The Myth of Race. The goal of Sussman's book is to discredit research about race and intelligence, and it therefore rejects the conclusions of differential psychology and behavioral genetics about the measurability and genetic basis of human intelligence. ${ }^{76}$ However, on a more fundamental level, the heritability of intelligence is itself one aspect of the broader heritability of variance in human psychological traits. ${ }^{77}$ One of the best-known studies about the overall heritability of human psychological variation is Thomas Bouchard's Minnesota Study of Identical Twins Reared Apart, ${ }^{78}$ so Sussman argues that Bouchard's credibility must be rejected as well. Like the YEC discussions of Egypt and feathered dinosaurs, Sussman makes some superficially empirical criticisms of Bouchard's study, but he also explains that his underlying reason for rejecting the study's conclusions is their potential to support research about race:

72 Ashton, J., \& Down, D. (2006). Unwrapping the Pharaohs: How Egyptian Archaeology Confirms the Biblical Timeline. Green Forest, AR: Master Books.

73 Bates, G. (2014). Egyptian chronology and the Bible-Framing the issues. Creation Ministries International. Retrieved 24 April 2020, from https://creation.com/egypt-chronology.

74 Gillborn, D. (2016). Softly, softly: Genetics, intelligence and the hidden racism of the new geneism. Journal of Education Policy, 31 (4), 365-88. doi:10.1080/02680939.2016.1139189.

75 Gillborn 2016.

76 Sussman, R. W. (2014). The Myth of Race: The Troubling Persistence of an Unscientific Idea (p. 240). Cambridge, MA: Harvard University Press.

77 For a large meta-analysis of the heritability of many physiological and psychological traits, including intelligence, see: Polderman, T. J., Benyamin, B., De Leeuw, C. A., Sullivan, P. F., Van Bochoven, A., Visscher, P. M., \& Posthuma, D. (2015). Meta-analysis of the heritability of human traits based on fifty years of twin studies. Nature Genetics, 47 (7), 702-9. doi:10.1038/ng.3285.

78 Bouchard, T. J., Lykken, D. T., McGue, M., Segal, N. L., \& Tellegen, A. (1990). Sources of human psychological differences: The Minnesota study of twins reared apart. Science, 250 (4978), 223-28. doi:10.1126/science.2218526. 
[... ] Bouchard and his researchers used study data to argue for the preponderance of genetics over environment as the main influence over behavior. Although race was not a focus of the MTFS [Minnesota Twin Family Study] research, it is important to remember that modern scientific racism is based on the argument that most human variation in such things as physiology, behavior, and intelligence is biologically based and is not determined or influenced in any important way by environment. ${ }^{79}$

Following Sussman's example, more recent books criticizing "race science" have done so by attacking behavioral genetics more broadly. In Angela Saini's Superior: The Return of Race Science, first Thomas Bouchard and then Robert Plomin are described as having inherited the "tarnished mantle" of Josef Mengele, the SS doctor of Auschwitz who is notorious for his cruel experiments upon humans, particularly on twins. ${ }^{80}$ A similar argument is made by Gavin Evans in Skin Deep: Journeys in the Divisive Science of Race, which transitions directly from a summary of Mengele's ghastly experiments to Evans' description of (and objections to) Plomin's research. ${ }^{81}$ In this respect, these antiracist academics are at odds with a large portion of academia because in the field of behavioral genetics Plomin is a completely mainstream figure-several standard textbooks on this topic include him as an author, he has a h-index of 161 , and his papers have been collectively cited over 110,000 times. $^{82}$

This denunciation of behavioral genetics raises the question of what these authors believe to be the actual source of variation in human psychological traits. Aside from her criticism of Bouchard and Plomin, Saini's book expresses relatively little opinion on this matter, except to say that "[t]he question of whether cognition, like skin colour or height, has a genetic basis is one of the most controversial in human biology". ${ }^{3}$ Sussman makes some general comments about the importance of culture in determining behavior, such as "culture defines biology rather than the other way around", ${ }^{84}$ but at no point does he go into detail about how he believes the two factors interact with one another or attempt to quantify the relative size of their contributions, as differential psychologists and behavioral geneticists have done. In a negative review of The Mismeasure of Man, Franz Samelson has criticized the same lack of specificity in Gould's attack on the "reification" of intelligence. Samelson writes, "Gould never tells us directly what his own proper, unreified conception of intelligence is". ${ }^{85}$ The reason for this approach is explained in a quotation from Lewontin, Rose and Kamin's book Not In Our Genes:

Critics of biological determinism are like members of a fire brigade, constantly being called out in the middle of the night to put out the latest conflagration, always responding to immediate emergencies, but never with the leisure to draw up plans for a truly fireproof building. [ ... ] Critics of determinism seem, then, to be doomed to

Sussman 2014, p. 250.

80 Saini, A. (2019). Superior: The Return of Race Science (pp. 224-25). London: HarperCollins.

81 Evans, G. (2019). Skin Deep: Journeys in the Divisive Science of Race (chapter 10). New York: Simon and Schuster.

82 "Robert Plomin". Google Scholar. Retrieved 9 May 2020, from https://scholar.google.com/citations? user= Nmt_xfwAAAAJ\&hl=en.

83 Saini 2019, p. 221.

84 Sussman 2014, p. 172.

85 Samelson, F. (1982). Intelligence and some of its testers. Science, 215 (4533), 656-57. doi:10.1126/science.215.4533.656. 
constant nay-saying, while readers, audiences, and students react with impatience to the perpetual negativity. ${ }^{86}$

Jonathan Kane has discussed the similar shortage of positive proposals among young-Earth creationists in their arguments about the origin of birds, which have usually attacked existing research without making any attempt at proposing an alternative explanation for the fossil data. Kane's criticism of this aspect of young-Earth creationism applies equally well to the equivalent aspect of cognitive creationism: "This is a destructive attitude because at its most basic level, science is about coming up with a model to explain what you observe, and testing whether your model's predictions match reality. If a person is not willing to propose a testable model, they aren't using the scientific method". ${ }^{87}$ Philosopher of science Imre Lakatos makes a similar point that a theory should be regarded as falsified if and only if another theory has been proposed that has greater explanatory power than the original theory. Lakatos writes, "the crucial element in falsification is whether the new theory offers any novel, excess information compared with its predecessor and whether some of this excess information is corroborated". ${ }^{88}$ (Emphasis in original.) However, when a theory is rejected on the basis of the creationist theory of knowledge and/or the domino effect, there is often no other specific theory to offer in its place. As a result, the arguments presented by both YEC and cognitive creationism tend to rely much more heavily on attacking others' models than on presenting their own testable models to explain the data.

\subsection{Lack of Parsimony}

Parsimony is the principle that a theory should not be any more complex than is necessary to explain the data. This principle was most famously articulated by William of Ockham: Frustra fit per plura, quod potest fieri per pauciora, meaning "In vain is done by many things, what can be done by few" ${ }^{89}$ Any body of evidence will have an indefinitely large number of nonparsimonious explanations, but there is usually only one or a few that are parsimonious. Due to their relative scarcity, developing a parsimonious explanation for a set of data depends on making a specific effort towards parsimony, so that if one's conclusion is chosen a priori and the evidence is forced to conform to that conclusion, the resulting models are very unlikely to be parsimonious.

Among young-Earth creationists, an example of this outcome can be seen in the YEC explanation for age measurements produced by radiometric dating, which was developed by a project known as Radioisotopes and the Age of The Earth (RATE). This project was an eight-year research program by the Institute for Creation Research and the Creation Research Society, whose conclusions were published in two large volumes in 2000 and 2005 , as well as a shorter summary volume. ${ }^{90}$ The central proposal underlying most of

86 Lewontin, R. C., Rose, S., \& Kamin, L. J. (1984). Not In Our Genes: Biology, Ideology, and Human Nature (p. 265). New York: Penguin.

87 Kane, J. (2016). Created kinds and the origin of birds. In J. Kane, E. Willoughby, T. M. Keesey, G. Morton \& J. Comer. God's Word or Human Reason?: An Inside Perspective on Creationism (pp. 105-80). Portland, OR: Inkwater Press.

88 Lakatos, I. (1999). Falsification and the methodology of scientific research programs. In T. Schick, Jr. (Ed.), Readings in the Philosophy of Science (pp. 20-26). Mountain View, CA: Mayfield Publishing Company.

89 Gernert, D. (2007). Ockham's razor and its improper use. Journal of Scientific Exploration, 21 (1), 135-40.

90 Isaac, R. (2007). Assessing the RATE project. Perspectives on Science and Christian Faith, 59 (2), 143-46. 
RATE's models is that nuclear decay rates have fluctuated over time due to alterations to the universe's physical constants and that the decay of most isotopes was accelerated by millions of times during Noah's flood, in order to account for radiometric data showing ages in the millions or billions of years within a young-Earth timescale. ${ }^{91}$

However, due to the lethal radiation that would have been produced by accelerated decay of carbon-14 within people's bodies, RATE has proposed that the decay rate of that particular isotope has remained constant. The dates produced by carbon-14 dating are instead proposed to represent large fluctuations in how much of this isotope was present in the environment. ${ }^{92}$ In order to account for the problem of radiation produced by potassium-40, another radioisotope found in the human body whose decay RATE believes was sped up, they have proposed that the pre-Flood environment did not contain any radioactive potassium, and thus people did not begin to incorporate this isotope into their bodies until after the Flood was over and decay rates returned to their normal levels. Finally, in order to deal with the massive amount of heat that accelerated decay would have produced, RATE has proposed a model of "cosmological cooling" involving the rapid expansion of the universe. ${ }^{93}$

Emily Willoughby has pointed out several ways in which this model is not adequate to explain all of the data. One problem is that the sun contains proportionally much less radioactive material than the Earth does, so if RATE's cosmological cooling mechanism had been adequate to offset the amount of heat produced by accelerated decay on Earth, it would have also cooled the sun to far below its normal temperature, causing its light-emitting layer to go out. In addition, RATE's argument that the pre-Flood environment contained no radioactive potassium is contradicted by geological data. According to RATE's model, Precambrian sediments are those that were deposited before the Flood, but measurable amounts of radioactive potassium are regularly found in Precambrian sedimentary rocks, indicating that radioactive potassium was present in the environment where these sediments were deposited. ${ }^{94}$ As the young-Earth creationist community updates their model of nuclear decay to take criticisms such as Willoughby's into account, its model to explain radiometric data is likely to become even more complicated than it is already.

Like the various lines of geological evidence that Earth is billions of years old, behavioral genetics contains several separate lines of data that point towards the same conclusion: that genes account for about $50 \%$ of the variation in human intelligence, rising to a maximum of $60 \%-80 \%$ in early adulthood. This conclusion-which refers to differences between individuals, not between group averages-is supported by studies of the similarity of monozygotic twins reared apart, ${ }^{95}$ studies comparing the degree

91 DeYoung, D. (2005). Thousands... Not Billions: Challenging the Icon of Evolution, Questioning the Age of the Earth (chapter 9). Green Forest, AR: Master Books.

92 Baumgardner, J. R. (2005). Carbon-14 evidence for a recent global flood and a young Earth. In L. Vardiman, A. A. Snelling \& E. F. Chaffin (Eds.), Radioisotopes and the Age of The Earth (vol. 2). El Cajon, CA: Institute for Creation Research.

93 Humphreys, D. R. (2000). Accelerated nuclear decay: A viable hypothesis? In L. Vardiman, A. A. Snelling \& E. F. Chaffin (Eds.), Radioisotopes and the Age of The Earth (vol. 1). El Cajon, CA: Institute for Creation Research.

94 Willoughby, E. (2016). Radiometric dating and the age of the Earth. In J. Kane, E. Willoughby, T. M. Keesey, G. Morton \& J. Comer. God's Word or Human Reason?: An Inside Perspective on Creationism (pp. 57-98). Portland, OR: Inkwater Press.

95 Knopik et al. 2017, p. 172. 
of similarity between monozygotic and dizygotic twins reared together, ${ }^{96}$ studies of adopted children and siblings, ${ }^{97}$ and genome-wide complex trait analyses of unrelated individuals. ${ }^{98,99}$ The conclusion that intelligence has a partially genetic basis offers a parsimonious explanation for all of these lines of data, and hence it is the mainstream explanation presented in textbooks about differential psychology, human intelligence, and behavioral genetics. ${ }^{100,101,102}$

In his 2017 book Genes, Brains, and Human Potential, Ken Richardson presents an explanation for these data from the viewpoint that individual differences in human psychological traits lack any genetic basis. Richardson argues that the degree of similarity between monozygotic and dizygotic twins cannot isolate genetic effects on psychological traits because monozygotic twins are more likely to share a placenta in the womb, and also because their parents and friends are more likely to treat them similarly. ${ }^{103}$ With respect to identical twins reared apart, he argues that these data are invalid because the pairs of twins were not adequately separated-in some cases they were separated in early childhood instead of at birth, and in some cases they remained in contact with one another after being adopted. ${ }^{104}$ With respect to other adoption studies, he argues that the similarity of adopted children with their biological relatives is caused by a number of factors, including the stress of being adopted, the expectations of their adoptive parents, and the tendency of adoption agencies to place children in families of similar social classes to their biological parents. ${ }^{105}$ Finally, he explains the results produced by genome-wide complex trait analyses by arguing that people who belong to the same social class are more likely to be genetically similar, meaning that the GCTA method "seems to be only good for redescribing the history of the class structure of society". 106

In his discussion of twin studies, Richardson initially does not specify whether he believes the similarity between monozygotic twins to be entirely the result of the potential confounding factors he has brought up. However, in the book's conclusion, he clarifies that he does indeed believe that his criticisms entirely explain this data: "The data-most prominently from twin studies-are easily explained by the clear falsity of such

96 Haworth, C. M., Wright, M. J., Luciano, M., Martin, N. G., de Geus, E. J., van Beijsterveldt, C. E., Bartels, M., Posthuma, D., Boomsma, D. I., Davis, O. S., Kovas, Y., Corley, R. P., Defries, J. C., Hewitt, J. K., Olson, R. K., Rhea, S. A., Wadsworth, S. J., lacono, W. G., McGue, M., .. Plomin, R. (2010). The heritability of general cognitive ability increases linearly from childhood to young adulthood. Molecular Psychiatry, 15 (11), 1112-20. doi:10.1038/mp.2009.55.

97 Knopik et al. 2017, pp. 171-72.

98 Davies, G., Tenesa, A., Payton, A., Yang, J., Harris, S. E., Liewald, D., Ke, X., Le Hellard, S., Christoforou, A., Luciano, M., McGhee, L., Lopez, L., Gow, A. J., Corley, J., Redmond, P., Fox, H. C., Haggarty, P., Whalley, L. J., McNeill, G., ... Deary, I. J. (2011). Genome-wide association studies establish that human intelligence is highly heritable and polygenic. Molecular Psychiatry, 16 (10), 996-1005. doi:10.1038/mp.2011.85

99 Hill, W. D., Arslan, R. C., Xia, C., Luciano, M., Amador, C., Navarro, P., Hayward, H., Nagy, R., Porteous, D. J., Mclntosh, A. M., Deary, I. J., Haley, C. S., \& Penke, L. (2018). Genomic analysis of family data reveals additional genetic effects on intelligence and personality. Molecular Psychiatry, 23, $2347-62$. doi:10.1038/s41380-017-0005-1

100 Haier 2017, chapter 2.

101 Knopik et al. 2017, p. 172.

102 Ashton 2018, pp. 249-52.

103 Richardson, K. (2017). Genes, Brains, and Human Potential: The Science and Ideology of Intelligence (pp. 56-60). New York: Columbia University Press.

104 Richardson 2017, pp. 53-56.

105 Richardson 2017, pp. 60-62.

106 Richardson 2017, pp. 66-69. 
assumptions". ${ }^{107}$ He makes a similarly absolutist assertion about what IQ tests measure: "IQ scores, then, are merely a kind of redescription of the distribution of social power, with its consequences for people's thoughts, feelings, self-confidence and so on". ${ }^{108}$

Despite the complexity of Richardson's set of explanations, it is, like RATE's model of nuclear decay, still inadequate to explain all of the data. Richardson does not offer an explanation for cases in which monozygotic twins were misclassified by their parents as dizygotic, or vice versa, while still having a level of similarity consistent with studies of twins whose parents classified them correctly. ${ }^{109}$ He also does not attempt to explain cases in which the results of twin studies were corroborated by studies that correlated psychological similarity with other types of relatedness, such as between siblings, half-siblings, and children and parents. ${ }^{110,111}$ Finally, in his discussion about possible environmental confounding of twin studies, Richardson does not mention that in the largest meta-analysis of this type of confounding, its effect was found to be quite small, and that there was only one psychological trait-neuroticism-for which it has a substantial effect. ${ }^{112}$ As with RATE's model of nuclear decay, explaining these additional lines of data would require a model even more complex than the one Richardson has proposed.

The convoluted nature of RATE's and Richardson's arguments reflects another basic parallel between cognitive creationism and young-Earth creationism: both viewpoints rely heavily on ad hoc explanations that are not generalizable to any underlying principle. This is a characteristic of what Lakatos describes as "degenerate" lines of research. In Lakatos' view, a successful research program must do more than simply offer an explanation for the current data-it must make some new risky predictions, and these predictions must ultimately turn out to be consistent with future discoveries. ${ }^{113}$ In RATE's case, their model of helium diffusion in zircon crystals was capable of predicting results from the area where RATE conducted their experiments, but had no predictive validity in any other area. ${ }^{114}$ The same problem applies to the theory that intelligence or other psychological traits do not have a genetic basis. Due to its reliance on ad hoc explanations to explain each line of data, this theory has consistently failed to predict future results, while predictions made by behavioral genetics have generally been successful. ${ }^{115}$

107 Richardson 2017, p. 342.

108 Richardson 2017, p. 101.

109 Conley, D., Rauscher, E., Dawes, C., Magnusson, P. K., \& Siegal, M. L. (2013). Heritability and the equal environments assumption: Evidence from multiple samples of misclassified twins. Behavior Genetics, 43 (5), 415-26. doi:10.1007/s10519-013-9602-1.

110 Kendler, K. S., Ohlsson, H., Edwards, A. C., Lichtenstein, P., Sundquist, K., \& Sundquist, J. (2016). A novel sibling-based design to quantify genetic and shared environmental effects: application to drug abuse, alcohol use disorder and criminal behavior. Psychological Medicine, 46 (8), 1639-50. doi:10.1017/S003329171500224X.

111 Schwabe, I., Janss, L., \& Van Den Berg, S. M. (2017). Can we validate the results of twin studies? A census-based study on the heritability of educational achievement. Frontiers in Genetics, 8, 160. doi:10.3389/fgene.2017.00160.

112 Felson, J. (2014). What can we learn from twin studies? A comprehensive evaluation of the equal environments assumption. Social Science Research, 43, 184-99. doi:10.1016/j.ssresearch.2013.10.004.

113 Lakatos, I. (1974). Popper on demarcation and induction. In P. A. Schilpp (Ed.), The Philosophy of Sir Karl Popper (pp. 139-67). La Salle, IL: Open Court Publishing Co.

114 Christman, T. K. (2005). Critique of RATE group's zircon-helium diffusion project. Old Earth Ministries. Retrieved 24 March 2020, from http://www.oldearth.org/RATE_critique_he-zr.htm.

115 Urbach, P. (1974). Progress and degeneration in the 'IQ debate' (I). The British Journal for the Philosophy of Science, 25 (2), 99-135. doi:10.1093/bjps/25.2.99. 


\subsection{Postmodern Arguments}

It is difficult to concisely summarize the tenets of postmodernism, which constitute a large set of beliefs rather than a single worldview. However, most relevant to this paper are postmodern perspectives on science, which regard the scientific method as less a search for objective truth than a way of constructing viewpoints based upon cultural presuppositions. In a critical analysis of postmodern views on science, Paul Gross and Norman Levitt offer the following summary:

Although there is no true center, no foundational axiomatics, to the left-wing critiques of science, a few broad perspectives may be identified. Sociologists and social theorists, including quite a few Marxists, tend to produce what may be called "cultural constructivist" analyses, viewing scientific knowledge as historically and socially situated and encoding, in unacknowledged ways, prevailing social prejudices. The strongest and most aggressive versions of these theories view science as a wholly social product, a mere set of conventions generated by social practice. ${ }^{116}$

Many of these views on the scientific method are inspired by Thomas Kuhn's influential book The Structure of Scientific Revolutions. In this book, Kuhn argues that science progresses by a series of paradigm shifts, with each new paradigm grounded in the social beliefs and practices of a particular time and place. More significantly, Kuhn argues that reality is not directly knowable, as scientific facts cannot be understood independently of the paradigm that they are part of. Kuhn refers to this principle as the "theory-ladenness" of data. ${ }^{117}$

This view of science is appealing to those who subscribe to the creationist theory of knowledge, as it can obscure the inability of degenerate theories to make accurate predictions. Ken Ham, the president of Answers in Genesis, has invoked the concept of the theory-ladenness of data as an argument that there is no such thing as objective evidence for evolution:

My point is that if we Christians really understood that all evidence is actually interpreted on the basis of certain presuppositions, then we wouldn't be in the least bit intimidated by the evolutionists' supposed 'evidence.' [...] The bottom line is that it's not a matter of who has the better (or the most) 'facts on their side.' We need to understand that there are no such things as brute facts-all facts are interpreted. ${ }^{118}$ (Emphasis in original)

Answers in Genesis often refers to these presuppositions as "Evolutionary glasses" or "Biblical glasses", arguing that they change the appearance of the entire world in a similar way to how wearing a different set of eyeglasses would change its appearance. ${ }^{119,120}$ This idea has some important implications for the YEC worldview. If all evidence is

116 Gross. P., \& Levitt, N. (1998). Higher Superstition: The Academic Left and Its Quarrels with Science (p. 11). Baltimore: Johns Hopkins University Press.

117 Kuhn, T. S. (1962). The Structure of Scientific Revolutions. Chicago, IL: University of Chicago Press.

118 Ham, K. (2003). Searching for the magic bullet. Answers in Genesis. Retrieved 24 April 2020, from https://answersingenesis.org/evidence-for-creation/searching-for-the-magic-bullet/.

119 Mitchell, E. (2015). What if dinosaurs really had feathers? Answers in Genesis. Retrieved 11 May 2020, from https://answersingenesis.org/dinosaurs/feathers/what-if-dinosaurs-really-had-feathers/.

120 Ham, K. (2011). Wearing Biblical glasses. Answers in Genesis. Retrieved 11 May 2020, from https: //answersingenesis.org/blogs/ken-ham/2011/03/16/wearing-biblical-glasses/. 
interpreted based on certain presuppositions and can support either creationism or evolution depending on what "glasses" one uses to view the world, then evolution educators cannot merely be trying to promote good science, and their true motives warrant investigation. An article by Don Batten in the magazine Creation attempts one such investigation. According to Batten: "If we consider a Who's Who of those who are most visible in their public promotion and defence of evolution-since World War II, for example-a clear pattern emerges: they are virtually all avowed atheists!". Batten concludes:

We see, therefore, that evolution is foundational/necessary for their faith that there is no Creator and that everything made itself (i.e., evolution). So, that is why atheists are at the forefront in promoting the public acceptance of evolution-it promotes their atheistic faith. ${ }^{121}$

According to the cognitive creationist version of this argument, as it is impossible for scientific conclusions to be truly objective, the view that intelligence is heritable and measurable only reflects the social presuppositions of researchers who choose to work from that perspective. This view was popularized in The Mismeasure of Man by Stephen Jay Gould, who described his view of intelligence research (and science more generally) in the following passage:

I criticize the myth that science itself is an objective enterprise, done properly only when scientists can shuck the constraints of their culture and view the world as it really is. [...] Rather, I believe that science must be understood as a social phenomenon, a gutsy, human enterprise, not the work of robots programed to collect pure information. ${ }^{122}$

Gould goes on to argue against the existence of what Ken Ham disparagingly calls "brute facts". Gould writes, "Facts are not pure and unsullied bits of information; culture also influences what we see and how we see it". Additionally, he concludes, "science's potential as an instrument for identifying the cultural constraints upon it cannot be fully realized until scientists give up the twin myths of objectivity and inexorable march toward truth". ${ }^{123}$ In another case of synergy between cognitive creationists and young-Earth creationists, some of Gould's statements about the scientific method's lack of objectivity have been widely cited by young-Earth creationists as an argument against the existence of objective evidence for evolution. ${ }^{124,125,126,127}$

${ }^{121}$ Batten, D. (1997). A Who's Who of evolutionists. Creation, 20 (1), 32. Retrieved 24 April 2020, https: //creation.com/a-whos-who-of-evolutionists.

122 Gould 1996, p. 53.

123 Gould 1996, p. 55

${ }^{124}$ Batten, D. (2002). 'It's not science'. Creation Ministries International. Retrieved 24 April 2020, from https://creation.com/its-not-science.

125 Matthews, M. (2002). Shame on Time! Answers in Genesis and Creation Ministries International. Retrieved 24 April 2020, from https://answersingenesis.org/human-body/shame-on-time/ and https:// creation.com/shame-on-time.

126 Sarfati, J. (2006). Does ribozyme research prove Darwinian evolution? Creation Ministries International. Retrieved 24 April 2020, from https: //creation.com/does-ribozyme-research-prove-darwinian-evolution.

127 Ammi, K. (2009). Atheism. Creation Ministries International. Retrieved 24 April 2020, from https: //creation.com/atheism. 
Since Gould's time, the argument that there is no such thing as objective science has remained popular in the antiheredity literature. The modern incarnation of this argument is presented in Jonathan Marks' 2017 book Is Science Racist?, which devotes much of its third chapter to criticizing the premises of the scientific method. Marks summarizes these premises as follows:

Scientific thought is generally centered on a few assumptions that developed in seventeenth-century Europe. Paramount among them were (1) naturalism, that there is a perceptible world distinct from the supernatural world, which (despite points of contact) can be studied separately from it; (2), experimentalism, that parts of nature can be isolated and studied in miniature, as it were, under controlled conditions, producing results that can be generalized; (3) rationalism, that reason is the surest past to accurate knowledge; and (4) that accuracy is the single most desirable quality and goal of scientific activity. ${ }^{128}$

Marks goes on to state that "Anthropologically, all these assumptions are quite unusual", and explains why he perceives each premise to be flawed. He claims that the premise of naturalism is flawed because it is a characteristic of human thought to incorporate the supernatural into the natural; that the premise of experimentalism is flawed because it is impossible to replicate the same exact conditions in order to reproduce an experimental result; that the premise of rationalism is flawed because we cannot necessarily expect nature to behave in a rational way; and that the desire for accuracy is flawed because "[a]ccuracy is not desirable in many contexts; indeed, that may be an adequate description of politeness-a socially acceptable disregard for truth". In summary, he states that "while science strives for objectivity, in the realm of bio-political science the best you can hope for is to confront and transcend the biases of your predecessors, while making your own biases as transparent and benign as possible". ${ }^{129}$ In addition to his more general criticism of the scientific method, Marks reserves special contempt for those who propose a genetic explanation for group differences in average IQ scores, writing: "They are ideologically corrupted; nobody should care what they have to say about the subject". ${ }^{130}$ As has happened among young-Earth creationists, when one believes that objectivity in science is impossible, it is a near-inevitable conclusion that one's opponents who claim to be objective must in fact be motivated by covert biases.

It should be emphasized that this perspective about the scientific method is not confined to only a small group of people, and Marks' book has been praised by many other prominent individuals in the field of anthropology. ${ }^{131}$ The year after his book was published, a similar argument was presented in the Encyclopedia of Critical Psychology, in which Brent and Nathan Slife argue that "empiricism has clear 'value biases' that provide a privileging of certain aspects of our experience over others, yet these values are often presented to students as the 'facts' or 'logic' of science". ${ }^{132}$ The same argument was also presented by students at Middlebury College as part of their basis for protesting Charles Murray's appearance there: "Science has always been used to legitimize racism, sexism,

\footnotetext{
128 Marks, J. (2017). Is Science Racist? (chapter 3). Malden, MA: Polity Press.

129 Marks 2017, chapter 3.

130 Marks 2017, chapter 1.

131 Moser, C. (2019). "Is Science Racist?" book review. Areo Magazine. Retrieved 24 April 2020, from https://areomagazine.com/2019/01/18/is-science-racist-book-review/.

132 Slife, B., \& Slife, N. (2018). Empiricism: Essay. In T. Teo (Ed.), Encyclopedia of Critical Psychology (pp. 571-78). New York: Springer.
} 
classism, transphobia, ableism, and homophobia, all veiled as rational and fact, and supported by the government and state. In this world today, there is little that is true 'fact"'. 133

This viewpoint represents a particularly potent case of the domino effect, as it has the potential to undermine conclusions in far more fields than just psychology and genetics. If true objectivity in science is impossible, then how (for example) could anyone know with certainty that vaccines do not cause autism, and that the research concluding they do not cause it was not merely reflecting biases in favor of the pharmaceutical industry? Likewise, how could anyone trust the FDA when they say that foods produced from genetically modified crops are safe to eat, or trust climatologists that carbon dioxide emissions are contributing to climate change? Ironically, many of those who are most concerned about the possible social consequences of heredity research have shown very little concern about the possible consequences that could occur if their own arguments against the scientific method were to become widely accepted.

\section{Conclusion}

Despite their occupying opposite ends of the political spectrum, both young-Earth creationism and cognitive creationism have converged on a number of similar approaches. This similarity is an inevitable result of their shared reliance on the creationist theory of knowledge, because this theory's reversal of the scientific method makes it impossible to avoid outcomes such as the domino effect and the adoption of nonparsimonious explanatory ideas. Future examination may show whether the similarities described in this paper also exist among advocates of other worldviews that engage in morally based rejection of scientific conclusions, such as antivaccination and anti-GMO activists.

One difference between cognitive creationism and young-Earth creationism is that cognitive creationism has far more prominence and influence in academia than YEC does. For example, Sussman's and Richardson's books were published, respectively, by Harvard University Press and Columbia University Press, whereas young-Earth creationist books and papers are generally restricted to religious publishers and specialized creationism journals such as Creation Research Society Quarterly, Answers Research Journal and the Journal of Creation. This difference is also shown by the differing degrees of success opponents of either evolution or intelligence research have had in terms of preventing the teaching of the viewpoint they oppose. In the Western world, contemporary attempts to stop the teaching of evolution in public schools have usually failed, but a 2017 editorial published in Nature reported that the inclusion of intelligence research is "dying out" in college psychology curricula due to the fear of accusations of racism or elitism. ${ }^{134}$

Cognitive creationism's greater level of academic influence means that in general, it is capable of causing more harm than young-Earth creationism can, especially when large swaths of well-established research are rejected due to their potential to support morally unpalatable ideas. The opposition to Arthur Jensen's 1969 monograph that argued for a genetic component to group differences, as well as similar opposition to The Bell Curve, has led to widespread opposition to acceptance of the heritability of intelligence in general. ${ }^{135}$ Holly Dunsworth's proposal, that biology classes must

\footnotetext{
133 Quoted in: Sullivan, A. (2017). Is intersectionality a religion? New York Magazine. Retrieved 24 April 2020, from http://nymag.com/intelligencer/2017/03/is-intersectionality-a-religion.html.

134 Anonymous. (2017). Intelligence research should not be held back by its past. Nature, 545 (7655), 385-86. doi:10.1038/nature.2017.22021.

135 Wright, W. (1999). Born That Way: Genes, Behavior, Personality (chapter 14). New York: Routledge.
} 
emphasize evolution's allegedly racist implications instead of simply teaching it as a scientific theory, demonstrates how even an area seemingly disconnected from behavioral genetics may be adversely affected by the desire to oppose "biological determinism". This risk is particularly acute in the case of the argument that objectivity in science is impossible, which has the potential to undermine conclusions from a vast number of fields.

Aside from encouraging the distrust of established scientific conclusions, this last argument poses another hazard. While individual scientists do not always live up to the ideal of objectivity, bias in any individual's work usually can be corrected by later researchers, allowing scientific fields to move incrementally closer to an accurate understanding of reality. However, science's ability to correct itself can only function when a sufficient number of scientists regard accuracy and objectivity as goals worth pursuing in their critiques of one another's work. If scientific fields accept Marks' argument that "accuracy is not desirable in many contexts", and that scientists must (in Gould's words) "give up the twin myths of objectivity and inexorable march toward truth", those fields will become unable to meaningfully correct themselves. In this way, the argument that science cannot be objective might ultimately prove to be a self-fulfilling prophecy.

The COVID-19 pandemic has caused a situation in which many lives depend upon the scientific method's integrity and objectivity. For example, the widespread dissemination of inaccurate information about this virus, and about how to protect oneself from it, has impeded attempts to limit its spread. ${ }^{136}$ Whether society and academia regard the scientific method as the most effective available approach available for understanding reality, or whether they instead treat science as a political activity, may be the difference between life and death for those who are most vulnerable.

Young-Earth creationism is widely understood as contrary to the scientific method and is the subject of much well-deserved criticism from science educators. On the other hand, cognitive creationism generally attracts much less criticism and scrutiny than young-Earth creationism does, despite incorporating much of the same epistemology and being harmful for many of the same reasons. It would be valuable for science educators to recognize the close parallels between these two viewpoints, and the importance of making a concerted effort to combat them both.

Acknowledgments: The author would like to thank the individual researchers and reviewers who provided crucial feedback in developing this manuscript.

136 Mian, A., \& Khan, S. (2020). Coronavirus: The spread of misinformation. BMC Medicine, 18 (1), 89. doi:10.1186/s12916-020-01556-3. 